\title{
The sandfly fauna (Diptera: Psychodidae: Phlebotominae) of the Parque Estadual da Serra da Tiririca, Rio de Janeiro, Brazil
}

\author{
Andressa Alencastre Fuzari Rodrigues ${ }^{1}$, Vanessa de Araújo Barbosa ${ }^{1}$, \\ José Dilermando Andrade Filho², Reginaldo Peçanha Brazil1/+
}

\begin{abstract}
'Laboratório de Bioquímica, Fisiologia e Imunologia de Insetos, Instituto Oswaldo Cruz-Fiocruz, Rio de Janeiro, RJ, Brasil ${ }^{2}$ Centro de Referência Nacional e Internacional para Flebotomíneos, Centro de Pesquisas René Rachou-Fiocruz, Belo Horizonte, MG, Brasil

Cutaneous leishmaniasis (CL) in the state of Rio de Janeiro is sporadic and can be characterised as a peridomestic transmission that occurs in modified natural environments. The aim of this work was to study the fauna and ecological characteristics of sandflies in an environmentally protected area (the State Park of Serra da Tiririca) within the remnants of the Atlantic Forest in the municipalities of Niterói and Maricá and their possible relationship with leishmaniasis. Captures were performed using light traps during the night once a month for one year in both sylvatic environments and areas surrounding homes near the park. A total of 1,037 sandflies were captured, belonging to nine genera and 12 species: Evandromyia tupynambai (34.1\%), Migonemyia migonei (20.6\%), Brumptomyia cunhai (13.8\%), Micropygomyia schreiberi (9.7\%), Psathyromyia lanei (6.5\%), Brumptomyia nitzulescui (5.7\%), Evandromyia edwardsi $(5.4 \%)$, Nyssomyia intermedia (2.8\%), Evandromyia cortelezzii $(0.6 \%)$, Pintomyia bianchigalatiae $(0.5 \%)$, Lutzomyia longipalpis $(0.2 \%)$ and Sciopemyia microps $(0.1 \%)$. Both Mg. migonei and Ny. intermedia may be acting as vectors of $C L$ in this area.
\end{abstract}

Key words: Phlebotominae - leishmaniasis - Atlantic Forest - Niterói - Maricá - Rio de Janeiro

Leishmaniases are zoonotic diseases caused by various species of flagellate protozoans of the genus Leishmania Ross, 1903 (Gontijo \& de Carvalho 2003) that are naturally transmitted by sandflies (Diptera: Psychodidae: Phlebotominae). In the state of Rio de Janeiro (RJ), cutaneous leishmaniasis (CL) is characterised as being peridomestically transmitted, mainly due to the adaptation of some species of its insect vectors to modified natural environments, thereby involving domestic animals in the transmission cycle (Brazil et al. 1991, Madeira et al. 2006). With respect to visceral leishmaniasis (VL), RJ is also classified as a sporadic transmission area where both human and canine cases have been diagnosed. Cases of VL have been recently reported in the cities of Angra dos Reis and Mangaratiba, demonstrating the spread of this disease to other regions of the state (Marzochi et al. 1985, Cabrera et al. 2003, Madeira et al. 2006). de Paula et al. (2009) reported the first autochthonous case of canine VL in the municipality of Maricá, providing information regarding the geographical distribution of Leishmania (Leishmania) infantum in RJ.

This work was aimed at studying the fauna and ecological characteristics of sandflies in an environmentally protected area within the remnants of the Atlantic Forest and their relationship with leishmaniases in the metropolitan area of RJ.

doi: $10.1590 / 0074-0276130688$

+ Corresponding author: rpbrazil@ioc.fiocruz.br

Received 10 December 2012

Accpeted 22 April 2013
The State Park of Serra da Tiririca (PEST) was recently created to protect remnants of the Atlantic Forest that were extremely threatened by real estate speculation and other human activities (Barros 2008). The PEST is situated between the municipalities of Niterói and Maricá (Supplementary data) in RJ $\left(22^{\circ} 48^{\prime} 23^{\circ} 00^{\prime} \mathrm{S}\right.$ and $42^{\circ} 57^{\prime}$ $43^{\circ} 02^{\prime} \mathrm{W}$ ), located on the coastline of the Serra do Mar (Barros 2008), covering an area of 2,260 hectares.

Captures of sandflies were performed from May 2010-May 2011, averaging once a month, using HP light traps modified in accordance with the methods of Pinto et al. (2012). The traps were put in place in the afternoon and removed the following day. Each trap remained connected for at least $17 \mathrm{~h}$ and for a total of $204 \mathrm{~h}$ per trap. Eight HP traps were used, distributed in three areas. In area 1, two traps were located in the forest towards the park headquarters (Itaipuaçu), in Maricá. In area 2, four traps were set up in the forest of the park (Itacoatiara), in Niterói. In this area, most of the trails within the PEST are open to the public for tourism. However, we chose the side of the forest without open trails to minimise any anthropogenic changes. In area 3, two traps were set up within the peridomicile of a residence in Itaipu on the border of the Park. This residence includes a large field that limits the forest and the yard contains a small house, a few crops, fruit trees and a chicken coop (Supplementary data). Sandflies were identified following the taxonomic key provided by Galati (2003) and mounted specimens were deposited, in the collection of the National and International Sandfly Reference Centre, in Belo Horizonte. The nonparametric statistical chi-square test was used to investigate differences in density between the sexes. The frequency of each species was calculated via the constance index (CI) (Dajoz 1973). Species diversity was 
analysed with the Shannon index and the natural logarithmic base, in accordance with Matos et al. (1999).

Among the 1,037 captured sandflies, 552 were males $(53.2 \%)$ and 485 were females $(46.8 \%)$, which did not represent a significant difference. The sandfly fauna comprised 12 species (Table I): Brumptomyia cunhai (Mangabeira, 1942), Brumptomyia nitzulescui (Costa Lima, 1932), Evandromyia cortelezzii (Brèthes, 1923), Evandromyia edwardsi (Mangabeira, 1941), Evandromyia tupynambai (Mangabeira, 1942), Lutzomyia longipalpis (Lutz \& Neiva, 1912), Migonemyia migonei (França, 1920), Micropygomyia schreiberi (Martins, Falcão \& Silva, 1975), Psathyromyia lanei (Barretto \& Coutinho, 1941), Pintomyia bianchigalatiae (Andrade Filho, Aguiar, Dias \& Falcão, 1999), Nyssomyia intermedia (Lutz $\&$ Neiva, 1912) and Sciopemyia microps (Mangabeira, 1942). According to the CI, the species Ev. tupynambai, Mi. schreiberi, Br. cunhai, Br. nitzulescui, Ev. edwardsi and Ps. lanei were categorised as constant species (species present in $50 \%$ or more of the catches). The category of accessory species (found in $25-50 \%$ of the catches) included Pi. bianchigalatiae, Lu. longipalpis, Mg. migo$n e i$ and $N y$. intermedia, while the category of accidental species (present in less than $25 \%$ of the catches) included Ev. cortelezzii and Sc. microps (Table II, Supplementary data). Among the most abundant sandfly species, only Mg. migonei and Ev. tupynambai showed a peak during the summer season (data not shown).

All of the species found in this work have been recorded in other regions of RJ (de Aguiar et al. 1986, Rangel et al. 1990, Brazil et al. 1991, 2011, Oliveira et al. 1995, Souza et al. 2003, Alves 2007). Evandromyia was the most abundant genus in the collections, represented by the species Ev. cortelezzii, Ev. edwardsi and

\section{TABLE I}

Number and percentage of species males and females of sandflies distributed in forest areas and peridomicile in the park area of Niterói and Marica, state of Rio de Janeiro

\begin{tabular}{lccc}
\hline Species & $\begin{array}{c}\text { Male } \\
(\mathrm{n})\end{array}$ & $\begin{array}{c}\text { Female } \\
(\mathrm{n})\end{array}$ & $\begin{array}{c}\text { Total } \\
\mathrm{n}(\%)\end{array}$ \\
\hline Brumptomyia cunhai & 82 & 61 & $143(13.8)$ \\
Brumptomyia nitzulescui & 27 & 32 & $59(5.7)$ \\
Evandromyia cortelezzii & 3 & 3 & $6(0.6)$ \\
Evandromyia edwardsi & 21 & 35 & $56(5.4)$ \\
Evandromyia tupynambai & 113 & 241 & $354(34.1)$ \\
Lutzomyia longipalpis & 2 & 0 & $2(0.2)$ \\
Migonemyia migonei & 180 & 34 & $214(20.6)$ \\
Micropygomyia schreiberi & 51 & 50 & $101(9.7)$ \\
Nyssomyia intermedia & 23 & 6 & $29(2.8)$ \\
Pintomyia bianchigalatiae & 0 & 5 & $5(0.5)$ \\
Psathyromyia lanei & 49 & 18 & $67(6.5)$ \\
Sciopemyia microps & 1 & 0 & $1(0.1)$ \\
\hline Total & 552 & 485 & $1,037(100)$ \\
\hline
\end{tabular}

Ev. tupynambai. The most representative species, Ev. tupynambai, has been associated with rodents by Mangabeira (1942); this species accounted for $34.1 \%$ of all of the sandflies collected. The record reported here is the first of this species in Niterói and Maricá. Ev. tupynambai was present in the traps located in both the forest fragments and the peridomicile. This finding leads us to suggest that this species be considered common and well adapted to the sylvatic environment, but that it appears to be eclectic with respect to food sources due to captures in a chicken coop (Figure). Another characteristic of the sampled sandflies was the capture of a greater number of females compared with males, which does not support the findings of de Aguiar et al. (1985), who collected a greater number of males in light traps. Migonemyia was the second most abundant genus and was represented only by the species $M g$. migonei, which was the second most frequent. This species is widely distributed in all regions of Brazil and it has been recorded throughout almost the entire RJ (Rangel et al. 1986, Brazil et al. 1991, 2011, Souza et al. 2002, 2003).

$\mathrm{Mg}$. migonei was found only in the chicken coop in Itaipu (Figure) and was classified as belonging to the accessory category. However, we emphasise that $\mathrm{Mg}$. migo$n e i$ was observed at in a higher density in this ecotope compared with the results of a recent study by our group performed in Saquarema. It was also one of the most abundant species around houses (Brazil et al. 2011). This finding agrees with those of Rangel and Lainson (2003), who showed that $\mathrm{Mg}$. migonei displays a feeding habit characterised by a remarkable degree of anthropophily while also feeding on domestic animals, such as dogs. $M g$. migonei has been demonstrated to be naturally infected by flagellates in the state of São Paulo (Pessoa \& Pestana 1940, Pessoa \& Coutinho 1941) as well as by Leishma-

\section{TABLE II}

Total number of sandflies

and constance index (CI) found in the municipality of Niterói and Maricá, state of Rio de Janeiro

\begin{tabular}{|c|c|c|c|}
\hline \multirow[b]{2}{*}{ Species } & \multirow{2}{*}{$\begin{array}{c}\text { Total } \\
\text { (n) }\end{array}$} & \multicolumn{2}{|l|}{ CI } \\
\hline & & $(\%)$ & Classification \\
\hline Evandromyia tupynambai & 354 & 100 & Constant \\
\hline Micropygomyia schreiberi & 101 & 100 & \\
\hline Brumptomyia cunhai & 143 & 75 & \\
\hline Evandromyia edwardsi & 56 & 75 & \\
\hline Brumptomyia nitzulescui & 59 & 62.5 & \\
\hline Psathyromyia lanei & 67 & 62.5 & \\
\hline Pintomyia bianchigalatiae & 5 & 37.5 & Accessory \\
\hline Lutzomyia longipalpis & 2 & 25 & \\
\hline Migonemyia migonei & 214 & 25 & \\
\hline Nyssomyia intermedia & 29 & 25 & \\
\hline Sciopemyia microps & 1 & 12.5 & Accidental \\
\hline Evandromyia cortelezzii & 6 & 12.5 & \\
\hline
\end{tabular}


nia (Viannia) braziliensis in Ceará Baturité (Azevedo et al. 1990, de Queiroz et al. 1991) and, recently, with $L$. infantum in the state of Pernambuco (de Carvalho et al. 2010). In RJ, Rangel et al. (1986, 1990) observed Mg. migonei to be the second most commonly recorded species in Vargem Grande and Mesquita. In Vargem Grande, Mg. migonei was shown to be predominantly feeding on dogs, leading the authors to suggest a possible role of this species in the transmission of the agent of canine $\mathrm{CL}$, together with other vectors in that area.

$M g$. migonei and Ev. tupynambai together accounted for more than $50 \%$ of all species collected in this study and were present in all samples (Table I). Ny. intermedia is considered one of the main vectors of $C L$ in Brazil and forms a species complex with Nyssomyia neivai (Marcondes 1996). $N y$. intermedia exhibits a broad distribution in RJ, often being recorded as the most frequent species (Rangel et al. 1986, 1990, Brazil et al. 1991, 2011, Souza et al. 2003, Alves 2007). In the present study, this species was not found in sylvatic environments within the park, as observed in other sylvatic areas of the state (de Aguiar \& Soucasaux 1984, Afonso et al. 2007). It was present only in captures made in the peridomicile area in Itaipu and was classified as an accessory species. $N y$. intermedia has been implicated as a potential vector of $L$. braziliensis by Rangel et al. (1984), who recorded natural infections in areas endemic for CL in Jacarepaguá and Vargem Grande. This evidence regarding the predominance of $N y$. intermedia in areas of CL and its frequency in domiciliary areas contribute to its implication as the main vector of this disease (Rangel et al. 1990, Alves 2007). In previous studies conducted in this area (Brazil et al. 1989, 1991), Ny. intermedia has always appeared as the dominant species and at high densities. However, it appears that $\mathrm{Mg}$. migonei is now taking over as the dominant species in dwellings, with $\mathrm{Ny}$. intermedia appearing at a lower density. The natural infection of both Ny. intermedia and Mg. migonei collected in the Park of Pedra Branca, RJ, with L. (V.) braziliensis, as determined through polymerase chain reaction analysis by de Pita-Pereira et al. (2005), strongly suggested that both

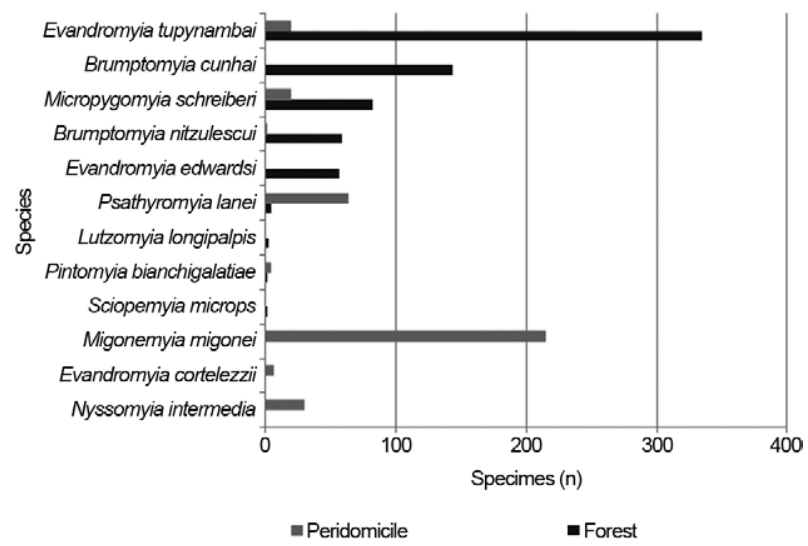

Number of species found in both environments of the State Park of Serra da Tiririca from May 2010-May 2011. species can play a role as vectors in the studied region. In $\mathrm{RJ}$, the distribution of $\mathrm{Lu}$. longipalpis is restricted to a few municipalities. However, with the detection of VL cases in the municipality of Rio de Janeiro, its presence in other municipalities has also been observed (de Souza et al. 1981, Rangel et al. 1986, 1990, Brazil et al. 1989, 2011, Cabrera et al. 2003).

In the present study, only two specimens of $L u$. longipalpis were captured in the forested area of Itacoatiara, representing the first report of this species in Niterói. This finding suggests that this population is predominantly sylvatic because it was never found in previous works in modified areas of this region (Brazil et al. 1991). However, Lu. longipalpis has previously been recorded in the municipalities of Rio Bonito and Saquarema (Brazil et al. 1989, 2011). Thus, further studies are needed to evaluate whether the population of Lu. longipalpis from Itacoatiara is actually an isolated population with an origin in the Atlantic Forest or displays a wider distribution in other regions of the state.

\section{ACKNOWLEDGEMENTS}

To the Institute of Environment and to the administration of the PEST, for logistic support.

\section{REFERENCES}

Afonso MM, Costa WA, Azevedo AC, Costa SM, Vilela ML, Rangel EF 2007. Data on sand fly fauna (Diptera, Psychodidae, Phlebotominae) in Itatiaia National Park, Rio de Janeiro state, Brazil. Cad Saude Publica 23: 725-730.

Alves JRC 2007. Espécies de Lutzomyia França (Diptera: Psychodidae, Phlebotominae) em área de leishmaniose tegumentar no município de Carmo, RJ. Neotrop Entomol 36: 593-596.

Azevedo ACR, Rangel EF, Costa EM, David J, Vasconcelos AW, Lopes UG 1990. Natural infection of Lutzomyia (Nyssomyia) whitmani (Antunes \& Coutinho, 1939) by Leishmania of the braziliensis complex in Baturité, Ceará state, Northeast Brazil. Mem Inst Oswaldo Cruz 85: 251.

Barros AAM 2008. Análise florística e estrutural do Parque Estadual da Serra da Tiririca, Niterói e Maricá, RJ, Brasil, $\mathrm{PhD}$ Thesis, Instituto de Pesquisas Jardim Botânico do Rio de Janeiro/Escola Nacional de Botânica Tropical, Rio de Janeiro, 218 pp.

Brazil RP, Brazil BG, Gouveia MC, Almeida DC, Oliveira SMP, Menezes JA 1989. Epidemiological studies on cutaneous leishmaniasis in the state of Rio de Janeiro, Brazil. Domestic and peridomestic sandfly fauna. In DT Hart, Leishmaniasis, NATO ASI Series, Vol. 163, Life Sciences Zakinthos, Zakinthos, p. 159-163.

Brazil RP, de Almeida DC, Brazil BG, Mamede SMPO 1991. Chicken house as a resting site of sandflies in Rio de Janeiro, Brazil. Parassitologia 33 (Suppl. 11): 113-117.

Brazil RP, Pontes MC, Passos WL, Rodrigues AA, Brazil BG 2011. The sand fly fauna (Psychodidae: Phlebotominae) in the region of Saquarema, state of Rio de Janeiro, Brazil, an endemic area of cutaneous leishmaniasis transmission. J Vector Ecol 36 (Suppl. 1): 95-98.

Cabrera MAA, Paula AA, Camacho LAB, Marzochi MCA, Xavier SC, Silva AVM, Jansen AM 2003. Canine visceral leishmaniasis in Barra de Guaratiba, Rio de Janeiro, Brazil: assessment of risk factors. Rev Inst Med Trop Sao Paulo 45: 79-83.

Dajoz R 1973. Ecologia geral, Vozes/EDUSP, São Paulo, 474 pp.

de Aguiar GM, Soucasaux T 1984. Aspectos da ecologia dos flebótomos do Parque Nacional da Serra dos Órgãos, Rio de Janeiro. 
I - Frequência mensal em isca humana (Diptera, Psychodidae, Phlebotominae). Mem Inst Oswaldo Cruz 79: 197-209.

de Aguiar GM, Vilela ML, Schuback PD, Soucasaux T, de Azevedo ACR 1985. Aspectos da ecologia dos flebótomos do Parque Nacional da Serra dos Órgãos, Rio de Janeiro. IV - Frequência mensal em armadilhas luminosas (Diptera, Psychodidae, Phlebotominae). Mem Inst Oswaldo Cruz 80: 465-482.

de Aguiar GM, Vilela ML, Soucasaux T 1986. Aspectos da ecologia dos flebótomos do Parque Nacional da Serra dos Órgãos, estado do Rio de Janeiro. V - Preferências alimentares (Diptera, Psychodidae, Phlebotominae). Mem Inst Oswaldo Cruz 81: 477-479.

de Carvalho MR, Valença HF, da Silva FJ, de Pita-Pereira D, de Araújo Pereira T, Britto C, Brazil RP, Brandão Filho SP 2010. Natural Leishmania infantum infection in Migonemyia migonei (França, 1920) (Diptera: Psychodidae: Phlebotominae) the putative vector of visceral leishmaniasis in Pernambuco state, Brazil. Acta Trop 116: $108-110$.

de Paula CC, Figueiredo FB, Menezes RC, Mouta-Confort E, Bogio A, Madeira MF 2009. Canine visceral leishmaniasis in Maricá, state of Rio de Janeiro: first report of an autochthonous case. Rev Soc Bras Med Trop 42: 77-78.

de Pita-Pereira D, Alves CR, Souza MB, Brazil RP, Bertho AL, de Figueiredo Barbosa A, Britto CC 2005. Identification of naturally infected Lutzomyia intermedia and Lutzomyia migonei with Leishmania (Viannia) braziliensis in Rio de Janeiro (Brazil) revealed by a PCR multiplex non-isotopic hybridisation assay. Trans R Soc Trop Med Hyg 99: 905-913.

de Queiroz RG, Vasconcelos AW, Vasconcelos Ide A, de Sousa RN, Pessoa FA, de Alencar JE 1991. Phlebotomine sandfly (Diptera: Psychodidae) fauna survey in an American cutaneous leishmaniasis (ACL) focus in Baturité, Ceará state, Northeast Brazil. Parassitologia 33 (Suppl. 11): 159-167.

de Souza MA, Sabroza PC, Marzochi MCA, Coutinho SG, de Souza WJS 1981. Leishmaniose visceral no Rio de Janeiro. 1 - Flebotomíneos da área de procedência de caso humano autóctone. Mem Inst Oswaldo Cruz 76: 161-168.

Galati EAB 2003. Morfologia e taxonomia. In EF Rangel, R Lainson (coord.), Flebotomíneos do Brasil, Fiocruz, Rio de Janeiro, p. 53-175.

Gontijo B, de Carvalho MLR 2003. American cutaneous leishmaniasis. Rev Soc Bras Med Trop 36: 71-80.

Madeira MF, Marzochi MCA, Schubach AO, Schubach TMP, Pacheco RS, Oliveira FS 2006. Mixed infection with Leishmania (Viannia) braziliensis and Leishmania (Leishmania) chagasi in a naturally infected dog from Rio de Janeiro, Brazil. Trans $R$ Soc Trop Med Hyg 100: 442-445.

Mangabeira Filho O 1942. $7^{\text {a }}$ contribuição ao estudo dos Flebotomus (Diptera: Psychodidae). Descrição dos machos de 24 novas espécies. Mem Inst Oswaldo Cruz 37: 111-218.

Marcondes CB 1996. A redescription of Lutzomyia (Nyssomyia) intermedia (Lutz \& Neiva, 1912) and resurrection of L. neivai
(Pinto, 1926) (Diptera, Psychodidae, Phlebotominae). Mem Inst Oswaldo Cruz 91: 457-462.

Marzochi MCA, Coutinho SG, de Souza WJS, de Toledo LM, Grimaldi Jr G, Momen H, Pacheco RS, Sabroza PC, de Souza MA, Rangel Jr FB, Tramontano NC 1985. Canine visceral leishmaniasis in Rio de Janeiro, Brazil. Clinical, parasitological, therapeutical and epidemiological findings (1977-1983). Mem Inst Oswaldo Cruz 80: 349-357.

Matos RMB, Silva EMRS, Berbara RLL 1999. Biodiversidade e indices, Embrapa-CNPAB, Documento 107, Embrapa Agrobiologia, Seropédica, $20 \mathrm{pp}$.

Oliveira SMP, Afonso RCH, Dias CMG, Brazil RP 1995. Estudo da fauna de flebotomíneos (Diptera: Psychodidae) em Santa Cruz, município do Rio de Janeiro, Brasil. Rev Brasil Entomol 39: 547-551.

Pessoa SB, Coutinho JO 1941. Infecção natural e experimental dos flebótomos pela Leishmania braziliensis no estado de São Paulo. Hospital 20: 23-35.

Pessoa SB, Pestana BR 1940. Infecção natural de L. migonei por formas em leptomonas provavelmente da L. braziliensis. Acta Med 5: 106-111.

Pinto IS, Tonini JFR, Ferreira AL, Falqueto A 2012. A brief inventory of sand flies (Diptera, Psychodidae) from the National Forest of the Rio Preto, state of Espírito Santo, southeastern Brazil. Biota Neotrop 12: 323-326.

Rangel EF, Azevedo ACR, Andrade CA, Souza NA, Wermelinger ED 1990. Studies on sandfly fauna (Diptera: Psychodidae) in a foci of cutaneous leishmaniasis in Mesquita, Rio de Janeiro state, Brazil. Mem Inst Oswaldo Cruz 85: 39-45.

Rangel EF, de Souza NA, Wermelinger ED, Barbosa AF 1984. Infecção natural de Lutzomyia intermedia Lutz \& Neiva, $1912 \mathrm{em}$ área endêmica de leishmaniose tegumentar no estado do Rio de Janeiro. Mem Inst Oswaldo Cruz 79: 395-396.

Rangel EF, Lainson R 2003. Ecologia da leishmanioses. In EF Rangel, R Lainson, Flebotómos do Brasil, Fiocruz, Rio de Janeiro, p. 291-336.

Rangel EF, Souza NA, Wermelinger ED, Azevedo ACR, Barbosa AF, Andrade CA 1986. Flebótomos de Vargem Grande, foco de leishmaniose tergumentar no estado do Rio de Janeiro. Mem Inst Oswaldo Cruz 81: 347-349.

Souza MB, Cardoso PG, Sanavria A, Marzochi MCA, Carvalho RW, Ribeiro PC, Ponte CS, Meira AM, Meródio JC 2003. Fauna flebotomínica do município de Bom Jardim, região serrana do estado do Rio de Janeiro, Brasil. Rev Bras Parasitol Vet 12: 150-153.

Souza NA, Andrade-Coelho CA, Vilela ML, Peixoto AA, Rangel EF 2002. Seasonality of Lutzomyia intermedia and Lutzomyia whitmani (Diptera: Psychodidae: Phlebotominae), occurring sympatrically in area of cutaneous leishmaniasis in the state of Rio de Janeiro, Brazil. Mem Inst Oswaldo Cruz 97: 759-765. 


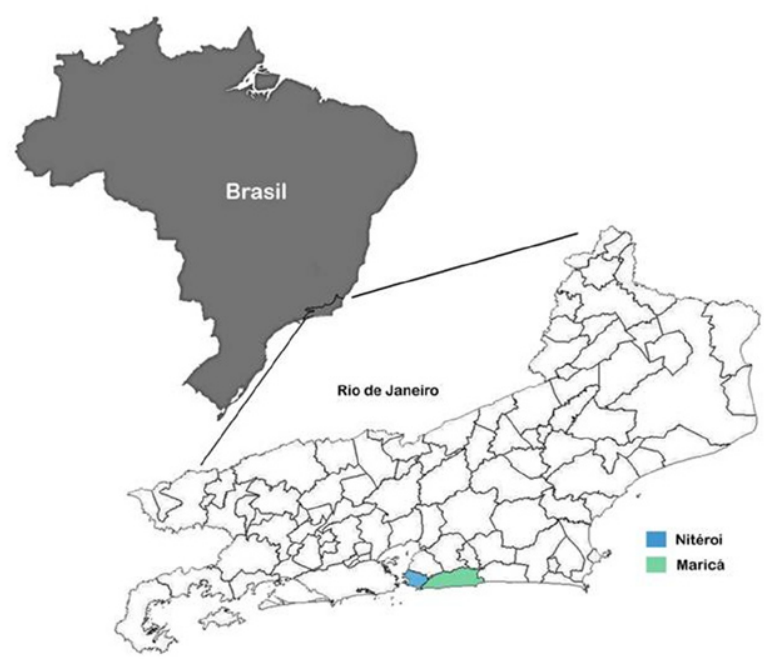

Map of the division of the state of Rio de Janeiro in municipalities (municipalities highlighted represent areas where the work was done).

Locations and environment type of the target areas with description of all points (each with a trap) and their geographical coordinates

\begin{tabular}{|c|c|c|c|c|}
\hline Area & Locality & Ambient & $\begin{array}{l}\text { Collection } \\
\text { points }\end{array}$ & $\begin{array}{l}\text { Geographic } \\
\text { coordinates }\end{array}$ \\
\hline \multirow[t]{2}{*}{1} & \multirow[t]{2}{*}{ Itaipuaçu } & \multirow[t]{2}{*}{ Forest } & 1 & $\begin{array}{l}\mathrm{S} 22^{\circ} 57^{\prime} 59.2^{\prime \prime} \\
\mathrm{O} 43^{\circ} 00^{\prime} 25.1^{\prime \prime}\end{array}$ \\
\hline & & & 2 & $\begin{array}{l}\mathrm{S} 22^{\circ} 57^{\prime} 55.9^{\prime \prime} \\
\mathrm{O} 43^{\circ} 00^{\prime} 24.0^{\prime \prime}\end{array}$ \\
\hline \multirow[t]{4}{*}{2} & \multirow[t]{4}{*}{ Itacoatiara } & \multirow[t]{4}{*}{ Forest } & 3 & $\begin{array}{l}\mathrm{S} 22^{\circ} 58^{\prime} 22.9^{\prime \prime} \\
\mathrm{O} 43^{\circ} 1^{\prime} 33.7^{\prime \prime}\end{array}$ \\
\hline & & & 4 & $\begin{array}{l}\mathrm{S} 22^{\circ} 58^{\prime} 24.0^{\prime \prime} \\
\mathrm{O} 43^{\circ} 1^{\prime} 33.7^{\prime \prime}\end{array}$ \\
\hline & & & 7 & $\begin{array}{l}\mathrm{S} 22^{\circ} 58^{\prime} 22.6^{\prime \prime} \\
\mathrm{O} 43^{\circ} 1^{\prime} 34.0^{\prime \prime}\end{array}$ \\
\hline & & & 8 & $\begin{array}{l}\mathrm{S} 22^{\circ} 58^{\prime} 23.1^{\prime \prime} \\
\mathrm{O} 43^{\circ} 1^{\prime} 33.5^{\prime \prime}\end{array}$ \\
\hline \multirow[t]{2}{*}{3} & \multirow[t]{2}{*}{ Itaipu } & \multirow[t]{2}{*}{ Peridomicile } & 5 & $\begin{array}{l}\mathrm{S} 22^{\circ} 56^{\prime} 46.9^{\prime \prime} \\
\mathrm{O} 43^{\circ} 00^{\prime} 52.9^{\prime \prime}\end{array}$ \\
\hline & & & 6 & $\begin{array}{l}\mathrm{S} 22^{\circ} 56^{\prime} 46.8^{\prime \prime} \\
\mathrm{O} 43^{\circ} 00^{\prime} 53.0^{\prime \prime}\end{array}$ \\
\hline
\end{tabular}


Number of sandfly species and diversity index (DI) found in Itacoatiara and Itaipu, municipality of Niterói, and Itaipuaçu, municipality of Maricá, state of Rio de Janeiro

\begin{tabular}{lcccc}
\hline & Area 1 & Area 2 & Area3 & \\
\cline { 2 - 4 } Species & $\begin{array}{c}\text { Itaipuaçu forest } \\
\text { (n) }\end{array}$ & $\begin{array}{c}\text { Itacoatiara forest } \\
\text { (n) }\end{array}$ & $\begin{array}{c}\text { Itaipu peridomicile } \\
\text { (n) }\end{array}$ & $\begin{array}{c}\text { Total } \\
\text { (n) }\end{array}$ \\
\hline Sciopemyia microps & 0 & 1 & 0 & 1 \\
Brumptomyia cunhai & 9 & 134 & 0 & 143 \\
Brumptomyia nitzulescui & 0 & 58 & 1 & 59 \\
Evandromyia cortelezzii & 0 & 0 & 6 & 6 \\
Evandromyia edwardsi & 2 & 54 & 0 & 56 \\
Evandromyia tupynambai & 31 & 304 & 19 & 354 \\
Lutzomyia longipalpis & 0 & 2 & 214 & 2 \\
Migonemyia migonei & 0 & 0 & 19 & 214 \\
Micropygomyia schreiberi & 5 & 77 & 29 & 101 \\
Nyssomyia intermedia & 0 & 0 & 4 & 29 \\
Pintomyia bianchigalatiae & 0 & 1 & 63 & 5 \\
Psathyromyia lanei & 1 & 3 & 355 & 67 \\
\hline Total & 48 & 634 & 1.27 & 1,037 \\
\hline DI & 1.04 & 1.43 & 0 & - \\
\hline
\end{tabular}

